\title{
The management of French public companies
}

by Frank Wooldridge

\section{INTRODUCTORY REMARKS}

$\mathrm{F}$ rench public companies make use of two 1 management structures. As is the situation in the majority of cases, they may have a single board of directors, but according to Article L225-57 of the French Commercial Code, they may adopt the dual board system either originally, or by a subsequent modification of their statutes. Under both board systems, a distinction may be made between the management and controlling functions.

In the past, the management of a single board company was carried out in practice by the chairman of the board (président directeur general or $P D G$ ) and a number of executive officers (directeurs généreaux délégués), but it is now possible for the managerial function to be given to another person. The other members of the board exercise a controlling function and have only a theoretical right to manage. In the two-board system, the supervisory board exercises a controlling function, whilst the executive board is responsible for management. Under both systems the general meeting retains certain controlling rights. Thus, in accordance with Article L232-1 it is responsible for the approval of the annual accounts and the management report: by Article L232-12, it is responsible for the apportionment of the profits.

The distinction between the management and controlling functions is more clearly defined under the dual board system than it is under the single board system. However, whilst it appears true to say that the duties and liabilities of the members of the supervisory board are less burdensome than those of the members of the board of directors (executive board) all such persons are subject to similar rules in particular areas, for example in relation to agreements with the company, and the age limit for holding office. These have been a number of changes in the rules concerning the boards of a public company and their members, in recent years, in particular by Law No 2001-420 of 15 May 2001: there was further legislation in 2002 (Law no 2002-1303 of 29 October 2002) and in 2003 (Law no 2003-706 of 1 August 2003). These laws amended the French Commercial Code. Such alterations have not taken place in the law concerning the management of a private company, although there have been changes in the law relating to the capital of such companies, making it unnecessary for such companies to have a nominal capital.

\section{THE SINGLE BOARD SYSTEM}

Both natural and legal persons may be directors of public companies. The directors and permanent representatives of legal persons who are appointed as directors are required to hold qualification shares in the company in accordance with its statutes. An exception is made for employee directors appointed in accordance with Article L225-23 of the Commercial Code when employee shareholding reaches 3 per cent. Such directors are appointed from the employees who are shareholders. A person who is not a shareholder may be elected as a director, but he is deemed in accordance with Article L225-25 to have resigned unless he becomes a shareholder within three months. The first directors are designated in the statutes except in the rare case when the company is formed as a public one, in which case Article L225-18 provides that they are appointed by the members. All other directors are appointed by the general meeting.

The total number of directors of a public company must be not less than 3 and no more than 18. There are two exceptions to this principle which are contained in Article L225-17. These are for directors appointed by employees who are shareholders in accordance with Article L225-23, and representatives of the employees appointed in accordance with Article L225-27. The former type of director is only appointed when employee shareholding reaches 3 per cent of the share capital. By Article L225-27, no more than four such representatives may be appointed to the board of directors if the statutes so permit. Such appointment will take place by the personnel of the company and of its French subsidiaries. This membership may be increased to five in the case of companies whose shares are admitted to dealings on a regulated market, but in no case may exceed one third of the number of other directors.

Directors who are appointed by the statutes cannot hold office for more than three years: if they are appointed by the general meeting, this period is increased to six years. These periods are provided for by Article L225-18, which also provides that directors may be re-elected unless the statutes otherwise provide. According to Article L225-19, the number of directors who are more than seventy years old may not exceed one third of the directors holding office, unless the statutes otherwise provide. Furthermore, unless they do so, when this proportion is not maintained, the oldest director is treated as having resigned. 
A director's office may terminate by retirement or dismissal. Although this position may be subject to criticism the French courts have decided that, by reason of certain principles of the law of agency contained in the Civil Code, dismissals may take place at any time by a resolution of the shareholders ordinary or extraordinary general meeting. This right cannot be restricted by the statutes or otherwise, and damages are only available if the dismissal occurred in prejudicial circumstances.

The general meeting may grant the directors a global sum for attendance fees (jetons de presence), and they may pay themselves reasonable remuneration for special tasks. It follows from Article L225-22 that an employee of the company may become a director and retain the benefit of this employment contract if it involves effective work, and his duties as an employee relate to a field of activity or responsibility other than as a director. A natural person cannot in principle serve on the board of directors of more than five public companies having their registered office in France. However, an exception to this rule contained in Article L225-21 exists where a natural person who is the director of a public company is also the director or member of the supervisory board of one or more of its subsidiaries with the meaning of Article L233-16. Such offices in unquoted subsidiaries are treated as constituting one for the purposes of Article L225-21, provided they do not exceed five. Legal persons may hold any number of directors' offices.

According to Article L225-35 of the Commercial Code, the board of directors determines the scope of the activities to be carried on by the company, and supervises their execution. Subject to the limitations imposed by a company's objects and the powers which are expressly granted to the general meeting (for example the approval of accounts), it has the power to deal with all questions involving the proper running of the company, and deliberates on matters which concern it. However, the board has limited itself in practice to defining the policies to be followed by the company. It carries out such controls and investigations as it thinks fit.

The business of the company is carried out by the directeur général, who may be a different person from the chairman, and by the executive officers (directeurs généraux délégués). As far as third parties are concerned limitations on business transactions imposed on the board by the statutes or otherwise have no effect, even where such transactions fall outside the ambit of the company's objects, unless it can be proved by the company that the third party knew that the transaction was outside the company's objects, or that such person should have known of this in the circumstances. Each director must be given all the information necessary to carry out his tasks, and all the documents that he deems necessary.

The board of directors are given specific powers and duties, for example preparing the annual accounts and drawing up an inventory of the assets (Article L232-1); calling general meetings (Article L225-103), and authorising all agreements between the company and its directeur général, one of its directors or executive officers (directeurs généraux délégués), or with a shareholder possessing more than ten per cent of the voting rights, or, if the latter is a corporate shareholder, agreements with its controlling company (Article L225-38). It is also responsible for appointing and dismissing the chairman of the board and the executive officers in accordance with the provisions of Articles L225-47 and L225-53.

The chairman (president du conseil d'administration), who is responsible for organising and directing the work of the board and supervising the functioning of the company organs, must be a natural person, and is appointed by the board of directors and may be reappointed. According to Article L225-47, his appointment may be terminated by the board at any time. The age limit is 65, unless the statutes contain a different provision (Article L225-48). A similar rule is made applicable to chairman (Article L225-54). The latter person, or another individual, may act as directeur général. The possibility of separating these two offices seems in accordance with modern ideas of corporate governance.

A person may not, according to Article L225-54-1, hold the office of directeur général in more than one company having its registered office in metropolitan France. There are exceptions to this rule which are applicable to the holding of one such office as directeur général or sole directeur général of a subsidiary of the relevant company, and for holding office as the directeur général or sole directeur général of an unquoted company. The restrictions on the appointment of employees as directors which have been mentioned above also apply to the directeur général.

According to Article L225-56, the directeur général has the widest powers to act on behalf of the company in all circumstances. He may not, however, encroach on the powers given to the general meeting or the board of directors by law, and is only permitted to exercise his powers within the limits of the company's objects. Nevertheless, his acts bind the company in relation to third parties in the same way as acts of the board of directors do.

Article L225-53 provides that the maximum number of executive officers (directeurs généraux délégués) who can be appointed to help the directeur général is five, and they are appointed by the board on the proposal of the directeur général. By Article L225-56 their powers in relation to third parties are the same as those of the directeur général. According to Article L225-55, they may be dismissed at any time by the board on the proposal of the directeur général. Article L225-55 also provides that if the latter dies, resigns or is dismissed from office, or is prevented from exercising his powers, they retain office until a new directeur général is appointed, unless the board decides otherwise. 
When a director is an executive officer, this office terminates with his directorship. Executive officers have the same powers as the chairman, as far as third parties are concerned.

\section{THE DUAL BOARD SYSTEM}

By Article L225-57, this system is only applicable if provided for in the company's statutes. It is now used by some large French companies, including Peugeot. The rules relating to traditional companies apply to companies having a dual board system with its exception of those contained in Articles L225-17 to Article L225-56, which apply to the single board. The executive board or directoire is collectively responsible for the management of the company's affairs, and corresponds to a certain extent to the directeur général of a company having a single board. Article L225-58 provides that the maximum number of members of the executive board is five, which is increased to seven in the case of companies whose shares are admitted to quotation on a regulated market. The number of members of the board is fixed by the statutes, and if they contain no relevant provision, by the supervisory board. If a public company's capital is less than 150,000 euros, the executive board may consist of one person (directeur général unique). The person who presides over meetings is called the president du directoire.

The members of the executive board must be natural persons, but need not be members of the company. They may be employees of the company at the time of their appointment, or become so subsequently. However, it follows from Article L225-74 that they may not be members of the supervisory board of the same company. Subject to exceptions for membership of one board of a company controlled by the relevant company, and for membership of the board of an unquoted company, Article L225-67 provides that it is only permissible to serve on the executive board of one French public company.

According to Article L225-62, the members of the executive board are appointed by the supervisory board for a period of between two and six years. By Article L225-61, they may be removed by the general meeting, and if the statutes so provide, by the supervisory board. Should such removal be without just cause, it will give rise to damages.

It follows from Article L225-64 that the members of the executive board may act collectively and bind the company in relation to third parties, in the same way as the board of directors of a traditional company. However, by way of exception, Article L225-68 provides that certain transactions require the approval of the supervisory board to be valid, such as the giving of guarantees, the sale of real property, or the creation of mortgages and charges over the company's assets. In addition, it also follows from Article L225-68 that (as in the German double board system), the statutes may provide that the conclusion of certain other transactions requires the consent of the supervisory board.
By Article L225-66, restrictions placed on the power of representation of the chairman of the executive board or the sole member thereof (directeur général unique) cannot be invoked by the company against third parties. The statutes may empower the supervisory board to confer the same power of representation with respect to third parties on one or more members of the executive board, who are then called executive officers (directeurs généraux).

The executive board is required by Article L225-68 to make a quarterly report on its management to the supervisory board. According to Article L225-100 the executive board is also required to prepare the company's annual accounts and report for submission to the annual general meeting.

The main function of the supervisory board is to exercise control over the executive board. Provided that the statutes so stipulate, representatives of the company's employees may be elected to the supervisory board and according to Article L225-79, they do not count in determining the maximum of eighteen or the minimum of three. The number of such members may not exceed four or one third of the other members in office. Members of the supervisory board elected thereto from the employees who are shareholders when employee shareholding exceeds 3 per cent are also disregarded, in accordance with Article L225-71, in determining the maximum and minimum. Legal as well as natural persons may be elected to the supervisory board, and such persons must, according to Article L225-76, appoint a person to be a permanent representative at board meetings.

The first members of the supervisory board are, according to Article L225-75, designated in the statutes and hold office for not more than three years. Subsequent members of the supervisory board, who are appointed by the general meeting (from among the shareholders) or the existing employees (from among their number), hold office for a period stipulated in the statutes, which may not exceed six years. As in the case of the directors of a traditional company, the members of the supervisory board may be dismissed at any time by the general meeting. A natural person cannot, in accordance with Article L225-77, belong at the same time to more than five supervisory boards of companies having their registered office in France. There are two exceptions to this rule, which are similar to those applicable to membership of the executive board.

By Article L225-81, the board elects a chairman and vice chairman from among its members, who have the task of presiding over board meetings. Article L225-82 stipulates that resolutions may only be passed if half the members are present. However, subject to certain exceptions, the internal rules of the company may provide that persons who participate by means of audio-visual links shall count for the purpose of determining quorums and majorities. The supervisory board is permitted by Article 
L225-68(3) to carry out such inspections and inquiries into the management of the company as it thinks appropriate, and it may demand access to any document which it deems necessary. It is also responsible for the appointment of members of the executive board and their chairman, and plays an important role in their dismissal. The supervisory board is also required by Article L225-68(6) to provide the annual general meeting with comments on the report of the executive board and the company's accounts.

\section{STATUTORY CONTROLS AND LIABILITIES}

Directors, directeurs généraux and executive officers (directeurs généraux délégues) of public companies adopting the traditional single board system as well as members of the executive and supervisory boards of such companies adopting the dual board system are subject to a number of statutory controls which have features in common. The purpose of the strict rules governing agreements between such persons and their company is to avoid a conflict between the interests of persons concerned and their duty to the company. According to Articles L225-43 and L225-91, the making of loans and giving of guarantees by companies to their directeur général directors and executive officers (directeurs généraux délégués) or to members of their executive and supervisory boards where the alternative dual board system is employed, is prohibited and void. The same rule applies to the personal representatives of legal persons which are members of the supervisory board or board of directors, and to the spouses, ascendants and descendants of persons covered by the relevant provisions. These prohibitions do not apply to current transactions entered into on the usual terms when the company is a bank or finance house.

The provisions of Articles L225-38 and L225-86 are concerned with agreements between a company and its directeur général, one of its directors or executive officers, and agreements between a company and a shareholder holding more than ten per cent of the voting rights, or with the controlling company of a corporate shareholder having such a holding; and where the dual board system is employed between a company and a member of its executive or supervisory board. The relevant provisions are in very similar terms. Furthermore, they are also applicable where there is an agreement entered into directly or indirectly between the company and one of the persons already mentioned; or between the company and another undertaking which is owned by a directeur général, executive officer, director or member of the executive or supervisory board, or in which such a person is a general partner, manager, director or member of the executive or supervisory board.

In cases in which a company has a traditional structure and the agreement is directly or indirectly with the directeur général, the directors or executive officers; or with the holders of more than 10 per cent of the voting rights, or with the controlling company of a corporation having such a holding it must receive the preliminary approval of the board of directors before execution. If the company has a dual board, and the agreement is directly or indirectly between a member of the supervisory or executive board and the company, or between the company and a person possessing more than ten per cent of the voting rights, or with the controlling company and the controlling company of a corporate shareholder having such a holding, it must be approved by the supervisory board before execution. Furthermore, Articles L225-40 and L225-88 make it clear that the contract must be notified to the auditor, reported on by him, and considered and approved at the general meeting. The interested party cannot vote on the agreement at the general meting and according to Article L225-40(1) and L225-88(2), his shares are not taken into account for the purpose of calculating the quorum or the majority. If the agreement is not approved by the general meeting, the company may claim damages from the relevant parties (which may include other directors or members of the executive board) for any loss suffered, even in the absence of fraud. This proposition follows from Article L225-41(2) and L225-89(2). However, by virtue of the provisions of Article L225-41(1) and L225-89(1), the agreement remains binding on the company unless it is annulled for fraud.

The rules relating to approval are stated by Article L225-39(1) and Article L225-87(1) to be inapplicable to current transactions entered into under normal conditions. However, such transactions need to be disclosed to the chairman of the board of directors or the supervisory board, who must provide a list of such transactions to the other members of the relevant board. This requirement does not have to be complied with in relation to transactions of an insignificant character, having regard to their object or financial implications.

The chairman, the directeur général, the directors and executive officers of traditionally managed public companies, and the members of the executive and supervisory boards of public companies adopting the dual board system are also require to comply with a number of more general rules. They must take account of the limitations on their powers provided for by law, in the statutes or otherwise, and refrain from acting outside the corporate purpose, as well as from taking any action which is not in the best interests of the company. According to Article L225-251 (as amended in 2001), the administrateurs (this term would seem to include directors and members of the executive board of a company having two boards) and the directeur général are responsible individually or jointly and severally, according to the circumstances, to the company or third parties for breach of the rules of law applicable to public companies, for breaches of the company's statutes and for faults in their management. If several administrateurs or several administrateurs together with the directeur général have taken part in the same wrong, the 
court has the task of determining the contribution of each party to the damages. Furthermore many types of dishonest or self-interested behaviour by directors are classified as criminal offences.

The shareholders may bring an action against the company if their personal rights have been infringed. By Article L225-252, minority shareholders may bring a derivative action against the administrateurs or the directeur général in the company's name if the company does not wish to bring such an action. It follows from Article L225-253 that the statutes may not subordinate the brining of such an action to the preliminary consultation, or the consent of, the general meeting. Individual shareholders or an association of shareholders with the meaning of Article L225-120 may bring such an action. Furthermore, a common representative may bring such an action in the shareholders name, if such shareholders represent a stated percentage of the capital, in accordance with the provisions of Articles 200 and 201 of Decree $67-$ 236, as amended.

\section{CONCLUDING REMARKS}

The rules governing the boards of French companies and their members are complex, and have perhaps been rendered more so by repeated legislation which has fortunately been consolidated in the Commercial Code. The position does not seem very different in the United Kingdom, where the possibility of revising and simplifying the complex provisions of Part X of the Companies Act 1985 (as amended) has been the subject of discussion by the Law Commission and the Scottish Law Commission, which published a joint report in 1999 (Cm4436)). There may be some scope for the simplification of certain provisions of French law concerning directors and related matters. In addition, there may be some possibility that the use of the double board system in France will be stimulated by legislation implementing the Regulation on the European Company, and the Directive which accompanies it, on employee involvement. (c)

Frank Wooldridge

\section{TWENTY-SECOND INTERNATIONAL SYMPOSIUM ON ECONOMIC CRIME}

\section{Sunday 5-Sunday 12 September 2004 Jesus College, University of Cambridge The Financial War on Terror and Organised Crime}

For further information contact Richard Alexander, Symposium manager, Jesus College, Cambridge CB5 8BL

Tel: +44 (0) 1223700943

Email:symposium@jesus.cam.ac.uk 